\title{
INDUSTRIAL MILK POWDER IN BIOASSAYS FOR EVALUATION OF CYTOTOXICITY AND GENOTOXICITY
}

\author{
LEITES INDUSTRIALIZADOS, TIPO EM PÓ, FRENTE A BIOENSAIOS DE \\ AVALIAÇÃO DE CITOTOXICIDADE E GENOTOXICIDADE
}

\author{
Rayssa Aléxia Martins MOURA ${ }^{1}$; Marcia Maria Mendes MARQUES ${ }^{2}$, \\ Helena Mendes PEREIRA ${ }^{3}$; Ila Monize Sousa SALES ${ }^{1}$; Fabelina Karolyne Sousa SANTOS ${ }^{1}$; \\ Maria Izabel Florindo GUEDES ${ }^{4}$; Ana Paula PERON ${ }^{2,5}$ \\ 1. Acadêmica do Curso de Ciências Biológicas - CSHNB, Universidade Federal do Piauí - UFPI, Picos, PI, Brasil; 2. Laboratório de \\ Citogenética e Mutagênese - LaCM - CSHNB, Universidade Federal do Piauí - UFPI, Picos, PI, Brasil; 3. Acadêmica do Curso de \\ Nutrição, Universidade Estadual do Ceará - UECE, Fortaleza, CE, Brasil; 4. Laboratório de Biotecnologia e Biologia Molecular - \\ LBBM, Programa de Pós-graduação RENORBIO/CE - UECE, Fortaleza, CE, Brasil; 5. Programa de Pós-graduação em Genética e \\ Melhoramento - PPGM - UFPI, Teresina, PI, Brasil. anapaulaperon@ufpi.edu.br
}

\begin{abstract}
Considering the widespread consumption of milk powder by the general population as well as the lack of studies on the toxicity of such industrialized foods, this study evaluated the cytotoxic and genotoxic potential of powdered milk from four reputed companies in the food market of Brazil and other South American countries. Milk samples were evaluated in root meristem cells of Allium cepa L., at concentrations of 0.065 and $0.13 \mathrm{~g} / \mathrm{mL}$, for 24 and 48 hours of exposure; and by means of cell viability in culture of cells of normal lineage, via MTT test, for 24 hours, at concentrations of $0.016 ; 0.032 ; 0.065$ and $0.13 \mathrm{~g} / \mathrm{mL}$. The concentration $0.13 \mathrm{~g} / \mathrm{mL}$ was the one suggested for consumption in all milk packages evaluated in this study. In A. серa, we observed that the milks, at both concentrations and at the two exposure times investigated, reduced the cellular proliferation of root meristems demonstrating a significant cytotoxicity. Furthermore, $0.13 \mathrm{~g} / \mathrm{mL}$ milks at the exposure time of $24 \mathrm{~h}$ induced an expressive frequency of cellular alterations in the plant tissue, showing to be genotoxic. In the in vitro evaluation, three milks at $0.065 \mathrm{~g} / \mathrm{mL}$ and all milks at $0.13 \mathrm{~g} / \mathrm{mL}$ have significantly reduced cell viability, proving to be cytotoxic to the analyzed cell culture. Therefore, under the studied conditions, the powdered milks evaluated caused significant genetic instability to the cells of the test systems used.
\end{abstract}

KEY WORDS: Powdered milk. Cell division. Mitotic spindle changes. Cell viability. Meristematic tissue. MTT test.

\section{INTRODUCTION}

Due to the abundance of unsaturated lipids, saccharides, vitamins and minerals, cow milk is considered one of the most complete nutritional foods for the human diet and therefore marketed and consumed worldwide (TAFFAREL et al., 2015). Among the options of industrialized milk offered to the consumer, the powdered or dehydrated milk is a variety of great demand and consumption by the general population and, consequently, very profitable to the food sector (FORCHETTI; POPPI, 2016).

In Brazil, for example, internal market of dehydrated milk accounts for an average of US\$ 200 million annually, a condition that allowed dairy companies to invest in current technologies and, therefore, to elevate the country to the ranking of powdered milk-exporting countries (SIQUEIRA et al., 2011; AGUIAR et al., 2015). Here, dehydrated dairy foods are regulated and authorized for consumption and commercialization by the National Health Surveillance Agency (ANVISA), through the
Technical Regulation on the Identity and Quality of milk, powdered variety, instituted by Administrative Ordinance 146, as of March $7^{\text {th }}, 1999$ (BRASIL, 1999 SOUZA et al., 2014). This regulation was drafted based on the Codex Alimentarius determinations, which regulates worldwide the general rules of chemical composition, safety and labeling of food (BRASIL, 1999; PFLANZER et al., 2010).

Briefly, dehydrated milk is obtained by vacuum evaporation of fresh whole, semi-skimmed or skimmed milk, followed by spray-drying the concentrate until the powder is obtained (ABRANTES; SILVA-CAMPÊLO; SILVA, 2014). Such thermal procedures minimize the proliferation of microorganisms and provide longer shelf and storage life to milk without loss of nutritional and sensory properties, such as aroma, flavor and color (BALKER et al., 2015). However, although this dairy product is not supplemented with microingredients or synthetic additives with preservative, flavoring and coloring properties compounds considered in the food safety area as 
expressive spoilers of the diet and potent allergens to the human organism (KONISHI; HAYASHI; FUKUSHIMA, 2014; MOURA et al., 2016) artificial additives with emulsifying and anti-wetting action are added to this food during industrialization. The addition of such microingredients has the purpose of promoting the total dilution of the milk powder, as well as of significantly reducing the air moisture absorption or hygroscopic capacity of the milk powder during storage and after opened for consumption (AGUIAR et al., 2015; TAFFAREL et al., 2015).

However, ANVISA and the Codex Alimentarius state in their technical regulations that many additives in industrialized foods, such as antiwetting and emulsifying agents, have been insufficiently evaluated for their potential cytotoxic, genotoxic, mutagenic and carcinogenic effects (BRASIL, 1999; BRASIL, 2007; XU et al., 2013). As a result of this lack of studies on toxicity, to date, these microingredients have no Acceptable Daily Intake (ADI) defined, which allow the safe consumption of these food additives (BRASIL, 1999; BRASIL, 2007; ZAINEDDIN et al., 2012; SALES et al., 2017).

Thus, the relevance and urgency of conducting research that, by means of appropriate bioassays, evaluates the cytotoxic and genotoxic effects of food added with artificial microingredients, such as industrialized milks, with the purpose of properly securing the well-being of consumers. According to ANVISA, the results obtained from toxicological analysis of food additives and, especially, food supplemented with such compounds, are the basis for elaborating or modifying the documents that regulate the basic composition and the daily intake index (BRASIL, 2007, BEZERRA et al., 2016, SALES et al., 2017). However, a broad search in the scientific literature found no studies of toxicity evaluation of powdered milk.

The root meristem of Allium cepa $\mathrm{L}$. (onion) is considered in the scientific field as an efficient bioassay for the initial screening of genetic toxicity of chemical compounds because of the reduced chromosomal number $(2 \mathrm{n}=16)$, which favors the detection of mitotic spindle or aneugenic changes, and disturbances in cellular proliferation index (NEVES et al., 2014; BIANCHI; MANTOVANI; MARIN-MORALES; 2015). It is a bioassay accepted internationally by research agencies as an instrument for the evaluation with accurate sensitivity to analyze the cytotoxicity and genotoxicity of the substance of interest, since the results obtained demonstrate, in most cases, satisfactory similarity to those obtained through animal testing systems and in cell cultures (TÜKOĞLU, 2007; HERRERO et al., 2011; LACERDA; MALAQUIAS; PERON, 2014; TABREZ et al., 2011; GOMES et al., 2013; OLIVEIRA et al., 2013; CAMPOS; MARINMORALES, 2016; MOURA et al., 2016, SANTANA et al., 2016).

Another important method in the preliminary evaluation of cytotoxicity is the cell viability observed in culture of cells exposed to compounds or substances of interest (MARQUES et al., 2015). Such viability can be measured by reduction of the MTT salt, 3-(4,5-dimethylthiazol-2yl)-2,5-diphenyltetrazolium bromide, also called tetrazolium salt, by means of the enzymatic pyruvate dehydrogenase complex present in the mitochondria. This complex transforms the tetrazolium salt into final metabolizing products called formazan crystals, which can be quantitatively measured (MOSMANN, 1983; MARQUES et al., 2015). Thus, the MTT test relies specifically on mitochondrial functionality, which allows the determination of cell viability or metabolism in cell lines against chemical compounds, and thus determines the cytotoxic potential of substances of interest (MOSMANN, 1983; MARQUES et al., 2015).

Given the above and considering the nutritional and economic importance of milk powder, as well as the lack of studies on the toxicity of this product and the microingredients added to its formulation during industrialization, the present study aimed to evaluate, in meristem root cells of Allium cepa and using the MTT test, the cytotoxicity and genotoxicity of samples of whole milk powder from reputed food companies in the Brazilian market, as well as in other South American countries. Whole milk was chosen for this evaluation because it is the most consumed by the Brazilian population.

\section{MATERIAL AND METHODS}

\section{Samples of powdered milk}

The brands of powdered milk - named in this study as A, B, C, D - manufactured by four different dairy companies with important performance in the food market of Brazil and other countries, were acquired in the retail market in the city of Picos, state of Piauí, Brazil, in August 2016. We were careful to check whether these foods were within the shelf life and the packaging were not violated and/or damaged. 


\section{Determination of powdered milk concentrations for evaluation.}

Milk samples were in packages containing a total of $130 \mathrm{~g}$ powdered product. On the labels, it was suggested to dissolve the whole milk content of the package in one liter of boiling water. Based on this, $0.065 \mathrm{~g} / \mathrm{mL}$ and $0.13 \mathrm{~g} / \mathrm{mL}$ concentrations were set for analysis in root meristems of $A$. серa, and in cell cultures, the concentrations of $0.016 ; 0.032$; 0.065 and $0.13 \mathrm{~g} / \mathrm{mL}$. The milk powder was dissolved in boiling distilled water and allowed to cool down to room temperature to then begin the toxicity assessment tests.

\section{Cytotoxicity and genotoxicity tests in root meristem cells of Allium cepa}

Initially, onion bulbs were placed in aerated bottles with distilled water at room temperature $( \pm$ $27^{\circ} \mathrm{C}$ ) until roots were $2.0 \mathrm{~cm}$ in length. For analysis of each milk sample, we established an experimental group with five onion bulbs. Before placing the roots in contact with their respective milk samples (treatments), some roots were collected and fixed to serve as control of the bulb itself. Then, the remaining roots were placed in their respective treatments for 24 hours, a procedure called 24 hour exposure time.

After 24 hours, some roots were taken and fixed. After this, the remaining roots of each bulb were returned to their respective treatments, where they remained for more 24 hours, which was called 48 hour exposure time. Next, roots were again collected and fixed. The 24 and 48 hour exposure times were chosen with the purpose of evaluating the action of milk powder diluted in more than one cell cycle. Roots were fixed in Carnoy 3: 1 (ethanol: acetic acid) for 24 hours. In each collection, on average, three roots was taken per bulb.

The slides, on average 03 per bulb, were mounted according to Guerra and Souza (2002), and analyzed under an optical microscope using objective lens 40X. For each onion bulb, we analyzed 1000 cells, totaling 5000 cells for each control, 24 hour exposure time and 48 hour exposure time of each treatment group under analysis. Thus, for each milk sample, we analyzed a total of 15,000 cells. Cells were observed in interphase, prophase, metaphase, anaphase and telophase. From this analysis, the mitotic index (MI) was determined by means of the following equation: (total number of cells in mitosis $\div$ total number of cells analyzed) $\mathrm{x} 100$. The $\mathrm{MI}$ value was a parameter used for the determination of the cytotoxic potential of the samples of milk under study.
In addition, we examined the genotoxicity of milk samples by the frequency of mitotic spindle alterations, considering C-metaphases, Multipolar anaphase, Anaphase and telophase bridges, Gene amplifications, Cells with adhesion, Nuclear buds and Micronuclei. For the statistical analysis of data on cytotoxicity and genotoxicity of the samples, we applied the chi-square test $(\chi 2)$, with $<0.05$ probability level.

\section{Cytotoxic activity evaluation against human tumor cell lines}

The cytotoxicity of powdered milk samples against Vero cells was evaluated by the MTT 3(4,5-dimethylthiazol-2-yl)-2,5-diphenyltetrazolium bromide (Sigma-Aldrich, Germany) method, through the quantization of viable cells (MOSMANN, 1983; MARQUES et al., 2015). The cells were cultured in 96-well plates (TPP, Trasadingen, Switzerland), at a density of $2 \times 10^{5}$ cells/well. After a 24 hour incubation period, at $37^{\circ} \mathrm{C}$ in an atmosphere of $\mathrm{CO}_{2}$, the culture medium was removed and the cells were washed three times with serum-free L-15, and powdered milk diluted up to $200 \mu \mathrm{L} / \mathrm{mL}$ in $\mathrm{MM}$ (L-15 medium with $2 \%$ serum) were added to the cells. Untreated controls were performed by the addition of $200 \mu \mathrm{L}$ of MM.

The cells were then incubated for 24 hours. The medium was then removed and $50 \mu \mathrm{L}$ of MTT solution $(5 \mathrm{mg} / \mathrm{mL})$ was added. The plates were reincubated for $4 \mathrm{~h}$. After, the MTT solution was removed, $100 \mu \mathrm{L}$ of DMSO was added to dissolve formazan crystals, and the plates were gently shaken, whereby crystals were completely dissolved. The solubilized product was quantified by spectrophotometry at $492 \mathrm{~nm}$ (reference at $620 \mathrm{~nm})$. Results were expressed as \% viability cell considering absorbance control cells as $100 \%$ viable.

\section{RESULTS AND DISCUSSION}

The results in Table 1 show that the two concentrations of all analyzed milk samples, when compared to the mitotic indices obtained for their respective controls, caused a significant reduction of cell division in the root meristems at both 24 and $48 \mathrm{~h}$ exposure times. For the concentration of 0.065 $\mathrm{g} / \mathrm{mL}$ of all milk samples, the mitotic index results found for the $48 \mathrm{~h}$ exposure time were statistically lower than their respective division indices observed for the $24 \mathrm{~h}$ exposure time. At the concentration of $0.13 \mathrm{~g} / \mathrm{mL}$, the values of the cell division index obtained for the milks of all the analyzed brands at the $24 \mathrm{~h}$ time of exposure were statistically similar to 
the values verified for their respective values of mitotic indices in the $48 \mathrm{~h}$ exposure time.

Table 1. Number of cells observed in each phase of the cell cycle of the root meristem tissue of Allium cepa exposed for 24 and 48 hours to samples of powdered milk diluted in distilled water, at the concentrations of 0.065 and $0.13 \mathrm{~g} / \mathrm{mL}$, of the food companies A, B, C and D. In each treatment, only significant $\chi 2$ values were presented.

\section{MITOTIC INDEX}

\begin{tabular}{|c|c|c|c|c|c|c|c|c|c|}
\hline Company & Concentration & $\mathrm{TE}$ & TCII & $\mathrm{P}$ & M & A & $\mathrm{T}$ & TCD & MI (\%) \\
\hline \multirow{6}{*}{ A } & \multirow{3}{*}{$0.065 \mathrm{~g} / \mathrm{mL}$} & $\mathrm{CO}$ & 3963 & 511 & 333 & 194 & 99 & 1037 & $22.7^{\mathrm{a}}$ \\
\hline & & $24 \mathrm{~h}$ & 4755 & 90 & 74 & 59 & 22 & 245 & $4.9^{\mathrm{b}}$ \\
\hline & & $48 \mathrm{~h}$ & 4987 & 09 & 03 & 01 & 00 & 13 & $0.3^{\mathrm{c}}$ \\
\hline & \multirow{3}{*}{$0.13 \mathrm{~g} / \mathrm{mL}$} & $\mathrm{CO}$ & 3937 & 398 & 300 & 271 & 94 & 1063 & $21.3^{\mathrm{a}}$ \\
\hline & & $24 \mathrm{~h}$ & 4967 & 14 & 09 & 01 & 09 & 33 & $0.7^{\mathrm{b}}$ \\
\hline & & $48 \mathrm{~h}$ & 4989 & 07 & 04 & 00 & 00 & 11 & $0.2^{\mathrm{b}}$ \\
\hline \multirow{6}{*}{ B } & \multirow{3}{*}{$0.065 \mathrm{~g} / \mathrm{mL}$} & $\mathrm{CO}$ & 3965 & 322 & 224 & 295 & 194 & 1035 & $21.0^{\mathrm{a}}$ \\
\hline & & $24 \mathrm{~h}$ & 4712 & 99 & 81 & 74 & 34 & 288 & $5.8^{\mathrm{b}}$ \\
\hline & & $48 \mathrm{~h}$ & 4954 & 32 & 13 & 00 & 01 & 46 & $0.9^{\mathrm{c}}$ \\
\hline & \multirow{3}{*}{$0.13 \mathrm{~g} / \mathrm{mL}$} & $\mathrm{CO}$ & 4177 & 347 & 199 & 156 & 121 & 823 & $16.5^{\mathrm{a}}$ \\
\hline & & $24 \mathrm{~h}$ & 4975 & 14 & 03 & 01 & 07 & 25 & $0.5^{\mathrm{b}}$ \\
\hline & & $48 \mathrm{~h}$ & 4986 & 04 & 09 & 01 & 00 & 14 & $0.3^{\mathrm{b}}$ \\
\hline \multirow{6}{*}{$\mathrm{C}$} & \multirow{3}{*}{$0.065 \mathrm{~g} / \mathrm{mL}$} & $\mathrm{CO}$ & 3913 & 378 & 354 & 201 & 154 & 1087 & $21.7^{\mathrm{a}}$ \\
\hline & & $24 \mathrm{~h}$ & 4770 & 74 & 89 & 54 & 13 & 230 & $4.6^{\mathrm{b}}$ \\
\hline & & $48 \mathrm{~h}$ & 4965 & 21 & 10 & 04 & 00 & 35 & $0.7^{\mathrm{c}}$ \\
\hline & \multirow{3}{*}{$0.13 \mathrm{~g} / \mathrm{mL}$} & $\mathrm{CO}$ & 3923 & 433 & 299 & 154 & 191 & 1077 & $21.5^{\mathrm{a}}$ \\
\hline & & $24 \mathrm{~h}$ & 4977 & 09 & 11 & 03 & 00 & 23 & $0.5^{\mathrm{b}}$ \\
\hline & & $48 \mathrm{~h}$ & 4984 & 09 & 07 & 00 & 00 & 16 & $0.3^{\mathrm{b}}$ \\
\hline \multirow{6}{*}{$\mathrm{D}$} & \multirow{3}{*}{$0.065 \mathrm{~g} / \mathrm{mL}$} & $\mathrm{CO}$ & 3982 & 389 & 243 & 208 & 178 & 1018 & $20.4^{\mathrm{a}}$ \\
\hline & & $24 \mathrm{~h}$ & 4810 & 44 & 79 & 54 & 13 & 190 & $3.8^{\mathrm{b}}$ \\
\hline & & $48 \mathrm{~h}$ & 4961 & 21 & 09 & 09 & 00 & 39 & $0.8^{\mathrm{c}}$ \\
\hline & \multirow{3}{*}{$0.13 \mathrm{~g} / \mathrm{mL}$} & $\mathrm{CO}$ & 3931 & 302 & 433 & 142 & 192 & 1069 & $21.4^{\mathrm{a}}$ \\
\hline & & $24 \mathrm{~h}$ & 4964 & 17 & 04 & 09 & 01 & 36 & $0.7^{\mathrm{b}}$ \\
\hline & & $48 \mathrm{~h}$ & 4984 & 13 & 03 & 00 & 00 & 16 & $0.3^{\mathrm{b}}$ \\
\hline
\end{tabular}

TCII - Total number of cells in interphase and undifferentiated cells; ET - Exposure Time; CO - Control; MI - Mitotic Index; TCD Total number of dividing cells. MI values followed by different letters within the same treatment are significantly different at $5 \%$ by $\chi^{2}$ test

Still for A. cepa, it is important to note that the concentration $0.13 \mathrm{~g} / \mathrm{mL}$, considered ideal for consumption by the manufacturers of the milks, drastically reduced the cellular division already at the $24 \mathrm{~h}$ exposure time. Finally, based on the results in Table 01, it can be inferred that the evaluated dairy products promoted significant inhibition of cell division to the plant test system, characterizing such foods as cytotoxic, under the study conditions.

According to Caritá and Marin-Morales (2008), severe damage occurs when there is pronounced antiproliferative effect in tissues with intense proliferation with normal metabolic performance - such as the root meristem tissues used in the present study - exposed to chemical compounds with potential to cause genetic instability. Such cytotoxic compounds, for the most part, have the potential to significantly impair the growth and function of the organs in which they are acting. Complementing the information of Caritá and Marin-Morales (2008), Gomes et al. (2013); Sales et al. (2017); Moura et al. (2016) and Carvalho et al. (2016) state that the inhibition of cell proliferation by cytotoxic compounds in tissues of high cell proliferation and normal functioning and/or without cell changes - again mentioning here the root meristems used as bioassays in the present study - is quite detrimental to the organism by inhibiting or limiting the replenishment of cells, altering the production of proteins and, consequently, resulting in malfunctioning of the organ or tissue where it is located. 
Table 2 shows that all analyzed milk samples, at a concentration of $0.065 \mathrm{~g} / \mathrm{mL}$ and at 24 hour exposure time, promoted a significant number of cellular alterations in the meristematic tissue of the roots, proving to be genotoxic. However, it is observed that the number of alterations at the $48 \mathrm{~h}$ analysis time was statistically lower than that observed for its respective $24 \mathrm{~h}$ analysis time. Such decline validates the results of cell inhibition presented in Table 01, since all milk samples at this concentration drastically reduced cell division at the highest exposure time considered. No cellular changes were observed in the meristems exposed to $0.13 \mathrm{~g} / \mathrm{mL}$ of the evaluated powdered milks. This condition also confirms the results in Table 01, once this concentration drastically inhibited cell division at the shortest exposure time considered.

Table 2. Number of cellular alterations observed in root meristem cells of Allium cepa exposed for 24 and 48 hours to samples of powdered milk diluted in distilled water, at the concentration of $0.065 \mathrm{~g} / \mathrm{mL}$, of the food companies A, B, C and D. In each treatment, only significant $\chi^{2}$ values were presented.

\begin{tabular}{|c|c|c|c|c|c|c|}
\hline Company & ET & $\begin{array}{c}\text { C- } \\
\text { Metaphase }\end{array}$ & $\begin{array}{c}\text { Anaphase and telófase } \\
\text { bridges }\end{array}$ & $\begin{array}{l}\text { Multipolar } \\
\text { Anaphase }\end{array}$ & Micronuclei & TAC \\
\hline \multirow{3}{*}{ A } & $\mathrm{CO}$ & 01 & 00 & 00 & 00 & $01^{\mathrm{a}}$ \\
\hline & $\begin{array}{c}24 \\
\mathrm{~h}\end{array}$ & 19 & 18 & 13 & 33 & $83^{\mathrm{b}}$ \\
\hline & $\begin{array}{c}48 \\
\mathrm{~h}\end{array}$ & 00 & 00 & 00 & 01 & $01^{\mathrm{a}}$ \\
\hline \multirow{3}{*}{ B } & $\mathrm{CO}$ & 00 & 00 & 00 & 01 & $01^{\mathrm{a}}$ \\
\hline & $\begin{array}{c}24 \\
\mathrm{~h}\end{array}$ & 11 & 13 & 19 & 49 & $82^{\mathrm{b}}$ \\
\hline & $\begin{array}{c}48 \\
\mathrm{~h}\end{array}$ & 00 & 00 & 02 & 00 & $02^{\mathrm{a}}$ \\
\hline \multirow{3}{*}{$\mathrm{C}$} & $\mathrm{CO}$ & 00 & 01 & 00 & 00 & $01^{\mathrm{a}}$ \\
\hline & $\begin{array}{c}24 \\
\mathrm{~h}\end{array}$ & 23 & 04 & 19 & 33 & $79^{\mathrm{b}}$ \\
\hline & $\begin{array}{c}48 \\
\mathrm{~h}\end{array}$ & 00 & 00 & 00 & 04 & $04^{\mathrm{a}}$ \\
\hline \multirow{3}{*}{$\mathrm{D}$} & $\mathrm{CO}$ & 00 & 00 & 00 & 01 & $01^{\mathrm{a}}$ \\
\hline & $\begin{array}{c}24 \\
h\end{array}$ & 21 & 13 & 09 & 24 & $67^{\mathrm{b}}$ \\
\hline & $\begin{array}{c}48 \\
\mathrm{~h}\end{array}$ & 04 & 00 & 00 & 01 & $05^{\mathrm{a}}$ \\
\hline
\end{tabular}

Aissa et al. (2012) claim that C-metaphases and multipolar anaphases occur in normal functioning tissues by the action of agents that affect the integrity of the nuclear spindle, promoting the correct alignment of chromosomes on the equatorial plate during cell division. Furthermore, Mazeo et al. (2011) report that bridges evidenced in anaphase and/or telophase cells are due to the action of compounds that significantly affect the functioning of the mitotic spindle during nuclear division, leading whole chromosomes to drift and give rise to micronuclei at the end of cell division. These authors also argue that these mitotic spindle variations, when recurrent, result in the generation of cells with distinct chromosome numbers.
Considering that the principle of the cell cycle is the formation of identical cells, the production of cells with a change in structure and/or chromosome number makes cell functioning infeasible and tend to be eliminated from tissues with normal performance. Based on information from Aissa et al. (2012) and Mazeo et al. (2011), it is possible to suggest the form of action of powdered milks evaluated herein in root meristems, inferring that the reduction of cell division in plant tissue (Table 01) occurred due to the significant promotion of cellular alterations to this test system (Table 02).

In the tetrazolium reduction test (Table 03), milk samples from companies $\mathrm{B}, \mathrm{C}$ and $\mathrm{D}$ at the 
concentration $0.065 \mathrm{~g} / \mathrm{mL}$ and all the samples analyzed at the concentration $0.13 \mathrm{~g} / \mathrm{mL}$ significantly reduced the cell viability of the culture exposed to the food in question, potentially toxic.
These data corroborate the cytotoxicity results described in Table 01. The samples evaluated at concentrations of 0.016 and $0.032 \mathrm{~g} / \mathrm{mL}$ were not cytotoxic to the culture of cells evaluated.

Table 3. Viability of Vero cells exposed for 24 hours to samples of powdered milk diluted in mineral water, and from four food companies, identified as A, B, C and D, at concentrations of $0.13 ; 0.065 ; 0.032$ and $0.016 \mathrm{~g} / \mathrm{mL}$, evaluated by the MTT reduction test.

\begin{tabular}{ccccc}
\hline \multicolumn{5}{c}{ \% Cell Viability } \\
\hline Groups & $0.016 \mathrm{~g} / \mathrm{mL}$ & $0.032 \mathrm{~g} / \mathrm{mL}$ & $0.065 \mathrm{~g} / \mathrm{mL}$ & $0.13 \mathrm{~g} / \mathrm{mL}$ \\
\hline CO & $99.57 \pm 0.98$ & $99.88 \pm 0.20$ & $100.03 \pm 0.75$ & $99.78 \pm 0.17$ \\
A & $89.57 \pm 2.50$ & $88.38 \pm 0.29$ & $88.08 \pm 1.10$ & $79.72 \pm 0.97^{*}$ \\
B & $89.72 \pm 3.84$ & $81.09 \pm 0.54$ & $78.79 \pm 2.28^{*}$ & $75.08 \pm 1.34^{*}$ \\
C & $88.50 \pm 2.00$ & $86.59 \pm 1.86$ & $78.57 \pm 2.18^{*}$ & $54.46 \pm 3.64^{*}$ \\
D & $89.03 \pm 5.19$ & $89.94 \pm 3.15$ & $74.22 \pm 1.35^{*}$ & $54.11 \pm 2.96^{*}$ \\
\hline
\end{tabular}

$\mathrm{CO}-$ Control. In each concentration, values followed by an asterisk are significantly different from the control by Tukey's Test $(P$ $<0.05)$.

According to the regulations of ANVISA (BRASIL, 1999), anti-wetting agents authorized for use in powdered milks are calcium phosphate, silicon dioxide, calcium carbonate and magnesium carbonate. There are no studies in the scientific literature evaluating cytotoxicity and genotoxicity for the dietary microingredients tricalcium phosphate and calcium carbonate. In turn, for the anti-wetting agent silicon dioxide, Rajiv et al. (2016) found that this compound had the property to significantly decrease the cell viability of human lymphocytes in normal cell culture, as well as to promote significant cellular changes, demonstrating a broad genotoxic potential. In relation to the magnesium carbonate, Ahamed et al. (2015) observed that this chemical had the ability to reduce cellular metabolism in human liver cell culture of normal lineage, showing to be significantly cytotoxic.

The results obtained by Rajiv et al. (2016) and Ahamed et al. (2015) corroborate our findings with A. cepa and MTT test. Nonetheless, these authors state that such research is still preliminary in the evaluation of toxicity of these food additives. With the exception of these two studies, no other studies were found in the literature on the toxicity at the cellular level of anti-wetting agents used in food. In relation to the microingredients of emulsifying action, the only permitted in Brazil for use in the composition of milk powder is lecithin (BRASIL, 1999), but toxicity studies on this microingredient have not been found in the literature. However, according to the Codex Alimentarius, other ingredients of emulsifying action, besides that mentioned above, can be used in the industrialization of milk powder, however, this surveillance body does not quote what compounds (SONBOL et al., 2013).

Therefore, the data obtained here through the meristem root cells of A. cepa and the MTT test showed that the dairy foods evaluated had a significant potential to cause toxicity at the cellular level, leading to an antiproliferative effect and the genotoxic effect to these bioassays. These results point out the need for these foods to be evaluated in physiologically more complex test systems, such as rodents, to investigate and deepen the results obtained here, once, according to Queiroz et al. (2015), cellular alterations and drastic reduction of cell division, when in an expressive way, as evidenced in the present study, has great potential in promoting neoplasms in mammals.

\section{CONCLUSIONS}

The dairy foods evaluated had a significant potential to cause toxicity at a cellular level with the concentration of $0.13 \mathrm{~g} / \mathrm{mL}$, indicated as ideal for consumption in the packages of the powdered milks studied.

These results indicate the need to evaluate the powdered milk in animal bioassays, from treatments with longer exposure times, to verify and deepen the results obtained here.

The results of genetic instability verified by the action of powdered milks are of great relevance since, to date, there are no toxicity studies published with such foods. 
RESUMO: Devido o amplo consumo de leite em pó pela população em geral, bem como, a carência de estudos sobre a toxicidade de tais alimentos industrializados, objetivou-se na presente pesquisa avaliar o potencial citotóxico e genotóxico de leites em pó provenientes de quatro empresas de reconhecida atuação no mercado de alimentos brasileiro e de outros países da América do sul. As amostras de leite foram avaliadas em células meristemáticas de raízes de Allium cepa $\mathrm{L}$., nas concentrações 0,065 e $0,13 \mathrm{~g} / \mathrm{mL}$, por 24 e 48 horas de exposição; e por meio da viabilidade celular em cultura de células de linhagem normal, via teste MTT, por 24 horas, nas concentrações 0,016;0,032;0,065 e 0,13g/mL. A concentração $0,13 \mathrm{~mL} / \mathrm{kg}$ foi a sugerida para consumo em todas embalagens de leites avaliados neste estudo. Em A. cepa, verificou-se que os leites, nas duas concentrações e nos dois tempos de análise considerados, reduziram a proliferação celular dos meristemas de raízes demonstrando citotoxicidade significativa. Ainda, os leites na concentração $0,13 \mathrm{~g} / \mathrm{mL}$ induziram, no tempo de exposição $24 \mathrm{~h}$, frequência expressiva de alterações celulares ao tecido vegetal, mostrando-se genotóxicas. $\mathrm{Na}$ avaliação in vitro, três leites na concentração $0,065 \mathrm{~g} / \mathrm{mL}$ e todos na concentração $0,13 \mathrm{~g} / \mathrm{mL}$ reduziram significativamente a viabilidade celular mostrando-se citotóxicos a cultura de células analisada. Portanto, nas condições de estudo estabelecidas, os leites em pó avaliados causaram significativa instabilidade genética as células dos sistemas testes utilizados.

PALAVRAS-CHAVE: Leite em pó. Divisão celular. Alterações de fuso mitótico. Viabilidade celular. Tecido meristemático. Teste mit.

\section{REFERENCES}

ABRANTES, M. R.; SILVA-CAMPÊLO, C.; SILVA, J. B. A. Fraude em leite: Métodos de detecção e implicações para o consumidor. Revista do Instituto Adolfo Lutz, São Paulo, v. 73, n. 3, p. 244-251, 2014. http://dx.doi.org/10.18241/0073-98552014731611 https://doi.org/10.18241/0073-98552014731611

AGUIAR, A. C. R. D.; ROCHA JÚNIOR, V. R.; CALDEIRA, L. A.; ALMEIDA FILHO, S. H. C. D.; RUAS, J. R. M.; SOUZA, V. M. D.; PIRES, D. A. D. A. Composição do leite de vacas alimentadas com diferentes fontes de compostos nitrogenados. Revista Brasileira de Saúde e Produção Animal, Salvador, v. 16, n. 3, 2015.

AHAMED, M.; ALHADLAQ, H. A.; AHMAD, J.; SIDDIQUI, M. A.; KHAN, S. T.; MUSARRAT, J.; ALKHEDHAIRY A. A. Comparative cytotoxicity of dolomite nanoparticles in human larynx HEp2 and liver HepG2 cells. Journal of Applied Toxicology, Philadelphia, v. 35, n. 6, p. 640-650, 2015.

http://dx.doi.org/10.1002/jat.3097 https://doi.org/10.1002/jat.3097

AISSA, A. F.; BIANCHI, M. L. P.; RIBEIRO, J. C.; HERNANDES, L. C.; FARIA, A. F.; MERCADANTE, A. Z.; ANTUNES, L.M.G. Comparative study of $\beta$-carotene and microencapsulated $\beta$-carotene: Evaluation of their genotoxic and antigenotoxic effects. Food Chemical and Toxicology, New York, v. 50, n. 5, p. 14181424, 2012. http://dx.doi.org/10.1016/j.fct.2012.02.030 https://doi.org/10.1016/j.fct.2012.02.030

BALKE, M.; KILIAN, J.; STEFFENS, C.; SOARES, M.; STEFFENS, J. Avaliação do processo de obtenção de leite em pó pelo processo de secagem em Spray Dryer. Blucher Chemical Engineering Proceedings, São Paulo, v. 1, n. 2, p. 4208-4215, 2015. https://doi.org/10.5151/chemeng-cobeq2014-1038-21449-163820

BEZERRA, M. D. S.; MALAQUIAS, G. D. S.; CASTRO E SOUSA, J. M. D.; PERON, A. P. Cytotoxic and genotoxic potential of powdered juices. Food Science and Technology, Campinas, v. 36, n. 1, p. 49-55, 2016. http://dx.doi.org/10.1590/1678-457X.006

BIANCHI, J.; MANTOVANI, M.S. Y MARIN-MORALES, M.A. Analysis of the genotoxic potential of low concentrations of Malathion on the Allium cepa cells and rat hepatoma tissue culture. Journal of Environmental Science, Pequim, v. 36, p. 102-111, 2015. http://dx.doi.org/10.1016/j.jes.2015.03.034 https://doi.org/10.1016/j.jes.2015.03.034

BRASIL. Agência Nacional de Vigilância Sanitária - ANVISA, 2007 [viewed 03 december 2016]. Resolucão da diretoria colegiada RDC $\mathbf{n}^{\mathbf{0}}$. 05, de 15 de Janeiro de 2007. Brasília: ANVISA. Available from: http://www.anvisa.gov.br/legis/resol/2007/rdc/02_170107rdc.pdf 
BRASIL. Agência Nacional de Vigilância Sanitária - ANVISA, 1999 [viewed 05 october 2016]. Resolução n. 17, de 30 de abril de 1999. Brasília: ANVISA. Available from:<http://bvsms.saude.gov.br/bvs/is_digital/is_0407/pdfs/IS27\%284\%29091.pdf>

CAMPOS-VENTURA, B.; MARIN-MORALES, M. A.; DESK S. Micronuclei and chromosome aberrations derived from the action of Atrazine herbicide in Allium cepa meristematic cells. SDRP Journal of Earth Sciences Environmental Studies, v.1, n. 1, p. s/n, 2016.

CARVALHO, F. R.; MOURA, A. G.; RODRIGUES, G. F.; NUNES, N. M.; LIMA, D. J.; PESSOA, C.; PERON, A. P. Are salty liquid food flavorings in vitro antitumor substances? Anais da Academia Brasileira de Ciências, v. 88, n. 3, p. 1419-1430, 2016. https://doi.org/10.1590/0001-3765201620150553

CARITÁ, R.; MARIN-MORALES, M.A. Induction of chromosome aberrations in the Allium cepa test system caused by the exposure of seeds to industrial effluents contaminated with azo dyes. Chemosphere, Oxford, v. 72, n. 5, p. 722-725, 2008. http://dx.doi.org/10.1016/j.chemosphere.2008.03.056 https://doi.org/10.1016/j.chemosphere.2008.03.056

FERNANDES, T. C. C, MAZZEO, D. E. C.; MARIN-MORALES, M. A. Mechanism of micronuclei formation in polyploidizated cells of A. cepa exposed to trifluralin herbicide. Pesticide Biochemistry and Physiology, San Diego, v. 88, n. 3, p. 252-259, 2007. http://dx.doi.org/10.1016/.pestpb.2006.12.003.

FORCHETTI, D. A.; POPPI, R. J. (2016). Use of NIR hyperspectral imaging and multivariate curve resolution (MCR) for detection and quantification of adulterants in milk powder. LWT-Food Science and Technology, v. 76, p. 337-343. http://dx.doi.org/10.1016/j.1wt.2016.06.046. https://doi.org/10.1016/j.lwt.2016.06.046

GOMES, K.M.S.; OLIVEIRA, M.V.G.A.; CARVALHO, F.R.S.; MENEZES, C.C.; PERON, A.P. Citotoxicity of food dyes sunset yellow (E-110), bordeax red (E-123), and tatrazine yellow (E-102) on Allium cepa $\mathrm{L}$. root meristematic cells. Food Science and Technology, Campinas, v. 33, n. 1, p. 218-223, 2013. . http://dx.doi.org/10.1590/S0101-20612013005000012 https://doi.org/10.1590/S0101-20612013005000012

GUERRA, M.; SOUZA, M.J. Como observar os cromossomos: um guia de técnicas em citogenética vegetal, animal e humana. Ribeirão Preto, SP, FUNPEC. 304p. 2002.

HERRERO, O.; MARTÍN, J. P.; FREIRE, P. F.; LÓPEZ, L. C.; PEROPADRE, A.; HAZEN, M. J. Toxicological evaluation of three contaminant of emerging concern by use of Allium cepa test. Mutation Research, Amsterdan, v. 743, p. 24-34, 2011. http://dx.doi.org/10.1016/j.mrgentox.2011.12.028 https://doi.org/10.1016/j.mrgentox.2011.12.028

KONISHI, Y.; HAYASHI, S. M.; FUKUSHIMA, S. Regulatory forum opinion piece*: supporting the need for international harmonization of safety assessments for food flavoring substance. Toxicologic Pathology, v. 42, n. 6, p. 949-953, 2014. http://dx.doi.org/10.1177/0192623313495603 https://doi.org/10.1177/0192623313495603

LACERDA, L. P.; MALAQUIAS, G.; PERON, A. P. Antiproliferative action of aqueous extracts of Hymenaea stigonocarpa Mart. (Fabaceae) on the cell cycle of Allium cepa L. Anais da Academia Brasileira de Ciências, Rio de Janeiro, v. 89, n. 3 p.1147-1150, 2014. http://dx.doi.org/10.1590/0001-3765201420130163 https://doi.org/10.1590/0001-3765201420130163

LEME. D. M.; MARIN-MORALES, M. A. Chromossome aberration and micronucleis frequencies in A. cepa cells exposed to petroleum polluted water - a case study. Mutation Research, Amsterdam, v. 650, p. 80-86, 2008. http://dx.doi.org/10.1016/j.mrgentox.2007.10.006 https://doi.org/10.1016/j.mrgentox.2007.10.006 
MARQUES, M. M. M.; MORAIS, S. M.; SILVA, A. R. A.; BARROSO, N. D.; PONTES FILHO, T. R.; ARAÚJO, F. M. C. ; VIEIRA, I. G. P.; LIMA, D. M.; GUEDES, M. I. F . Antiviral and Antioxidant Activities of Sulfated Galactomannans from Plants of Caatinga Biome. Evidence-Based Complementary and Alternative Medicine (Print), v. 2015, p. 1-8, 2015. http://dx.doi.org/10.1155/2015/591214 https://doi.org/10.1155/2015/591214

MOSMANN, T. Rapid colorimetric assay for cellular growth and survival: application to proliferation and cytotoxicity assays. Journal of Immunological Methods, v. 65, n. (1-2), p. 55-63, 1983.

MAZZEO, D.E.C.; FERNANDES, T.C.C.; MARIN-MORALES, M. A. (2011). Cellular damages in the Allium cepa test system, caused by BTEX mixture prior and after biodegradation process. Chemosphere, v. 85, n. 1, 13-18, 2011. https://doi.org/10.1016/j.chemosphere.2011.06.056

MOURA, A.G.; SANTANA, G.M.; FERREIRA, P.M.P.; SOUSA, J.M.C.; PERON AP. Cytotoxicity of Cheese and Cheddar Cheese food flavorings on Allim cepa L root meristems. Brazilian Journal of Biology, São Carlos, v. 76, n. 2, p. 439-443, 2016. http://dx.doi.org/10.1590/6484.20514

NEVES, E.S.; FERREIRA, P.M.P.; LIMA, L.H.; PERON, A.P. Action of aqueous extracts of Phyllanthus niruri L.(Euphorbiaceae) leaves on meristematic root cells of Allium cepa L. Anais da Academia Brasileira de Ciências, Rio de Janeiro, v. 86, n. 3, p. 1131-1137, 2014. http://dx.doi.org/10.12662/2317-

3076jhbs.v1i1.14.p27.2013 https://doi.org/10.12662/2317-3076jhbs.v1i1.14.p27.2013

OLIVEIRA, M.V.A.; ALVES, D.D.L.; LIMA, L.H.G.M.; CASTRO, J.M.C., PERON, A.P. Cytotoxicity of erytrosine (E-127), brilliant blue (E-133) and red 40 (E-129) food dyes plant test system. Acta Scientiarum. Biological Science, Maringá, v. 5, n. 4, p. 557-562, 2013. http://dx.doi.org/10.4025/actascibiolsci.v35i4.18419 https://doi.org/10.4025/actascibiolsci.v35i4.18419

PFLANZER, S.B.; CRUZ, A.G.D.; HATANAKA, C.L.; MAMEDE, P.L.; CADENA, R.; FARIA, J.A.F.; SILVA, M.A.A.P.D. Perfil sensorial e aceitação de bebida láctea achocolatada. Food Science and Technology, Campinas, v. 30, n. 2, p. 391-398, 2010. http://dx.doi.org/10.1590/S0101-20612010000200016 https://doi.org/10.1590/S0101-20612010000200016

QUEIROZ, F.M.D.; MATIAS, K.W.D.O.; CUNHA, M.M.F.D.; SCHWARZ, A. Evaluation of (anti) genotoxic activities of Phyllanthus niruri L. in rat bone marrow using the micronucleus test. Brazilian Journal Pharmacological Science, São Paulo, v. 49, n. 1, p. 135-148, 2015. http://dx.doi.org/10.1590/S198482502013000100015 https://doi.org/10.1590/S1984-82502013000100015

RAJIV, S.; JEROBIN, J.; SARANYA, V.; NAINAWAT, M.; SHARMA, A.; MAKWANA, P.; MUKHERJEE, A. Comparative cytotoxicity and genotoxicity of cobalt (II, III) oxide, iron (III) oxide, silicon dioxide, and aluminum oxide nanoparticles on human lymphocytes in vitro. Human \& Experimental Toxicology, v. 35, n. 2, p. 170-183, 2016. http://dx.doi.org./10.1177/0960327115579208 https://doi.org/10.1177/0960327115579208

SALES, I. M. S.; SOUSA, J. B.; SOUSA, F. K. S.; CAVALCANTI CARNEIRO DA SILVA, F. C. C.; FERREIRA, P. M. P.; SOUSA, J. M. C.; PERON, A. P. Acute Toxicity of Grape, Plum and Orange Synthetic Food Flavourings Evaluated in in vivo Test Systems. Food Technology and Biotechnology, Zagreb, v. 55. n. $551,2017$.

SANTANA, G. M.; DEUS, M. S. M.; SOUSA, J. M. C.; FERREIRA, P. M. P.; FERNANDES, H. B.; PERON, A. P. Antimitotic and antimutagenic action of the Hymenaea stigonocarpa bark on dividing cells. Brazilian Journal Biolology, São Carlos, v. 76, n. 2, p. 520 - 525, 2016. http://dx.doi.org/10.1111/1471-0307.12227 https://doi.org/10.1111/1471-0307.12227

SIQUEIRA, K. B.; ALMEIDA, M. F. Investigações Recentes de Dumping no Mercado Lácteo Brasileiro. Revista Informações Econômicas, São Paulo, v. 41, n. 8, 2011. 
SONBOL, H.; JOSEPH, S.; MCAULEY, C. M.; CRAVEN, H. M.; FORSYTHE, S. J. Multilocus sequence typing of Cronobacter spp. from powdered infant formula and milk powder production factories. International Dairy Journal, v. 30, n. 1, p. 1-7, 2013. https://doi.org/10.1016/j.idairyj.2012.11.004

SOUZA, L. V.; SOUZA, C. B.; MARTINS, M. L., PINTO, C. M. F.; OLIVEIRA, P. C. L. Avaliação da qualidade microbiológica e físico-química de leite UHT integral processado em indústrias do Estado de Minas Gerais, Brasil. Revista Brasileira de Agropecuária Sustentável, v. 4, n. 2, 2014.

TABREZ, S.; SAHKIL, S.; UROOJ, M.; DAMANHORI, G.A.; ABUZENADAH, A.M.; AHMAD D. Genotoxicity testing and biomarker studies on surface water: an over view of the techniques and their efficacies. Journal of Environmental Science and Health, v. 29, n. 3, p. 250-275, 2011.

http://dx.doi.org/10.1080/10590501.2011.601849. https://doi.org/10.1080/10590501.2011.601849

TAFFAREL, L. E.; COSTA, P. B.; OLIVEIRA, N. T. E.; BRAGA, G. C.; ZONIN, W. J. Total bacterial count of milk in different systems of milking and cooling. Arquivos do Instituto Biológico, São Paulo, v. 80, p.1, p. 07-1, 2013. http://dx.doi.org/10.1590/S1808-16572013000100002 https://doi.org/10.1590/S1808-

\section{2}

TÜRKOĞLU, Ş. Genotoxicity of five food preservatives tested on root tips of Allium cepa L. Mutation Research, Amsterdan, v. 626, p. 4-14, 2007. http://dx.doi.org/10.1016/j.mrgentox.2006.07.006 https://doi.org/10.1016/j.mrgentox.2006.07.006

XU, Z., GU, C., WANG, K., JU, J., WANG, H., RUAN, K.; FENG, Y., 2015. Arctigenic acid, the key substance responsible for the hypoglycemic activity of Fructus Arctii. Phytomedicine, Mainzv, 22, n. 1, p. 128-137, 2015. $\quad$ http://dx.doi.org/10.1016/j.phymed.2014.11.006. $\quad$ PMid:25636881. https://doi.org/10.1016/j.phymed.2014.11.006

ZAINEDDIN, A. K.; BUCK, K.; VRIELING, A.; GEINZ, J.; FLESCH-JANYS, D.; LINSEISEN, J. The association between dietary lignans, phytoestrogen-rich foods, and fiber intake and postmenopausal breast cancer risk: a German case-control study. Nutrition and Cancer. v. 64, n. 5, p. 652-665, 2012.

https://doi.org/10.1080/01635581.2012.683227 